logos_i_ethos_2019_special_issue,pp.7-39

DOI: http://dx.doi.org/10.15633/lie.3467

Piotr Duchliński

ORCID: https://orcid.org/0000-0001-9480-2730

\title{
Ontogenesis of the "why" question from the perspective of genetic epistemology, and its philosophical implications
}

\section{Preliminary remarks}

The "why" question has made a staggering career in philosophy, and particularly in metaphysics. ${ }^{1}$ Many philosophers consider that the question expresses the very essence of philosophy and is something specific to pursuing the philosophical discourse, as well as
Piotr Duchliński - a doctor with a habilitation degree in humanities, in the field of philosophy. In his research he focuses on the methodology and philosophy of humanities, metaphilosophy, epistemology, general ethics and axiology as well as 20th-century Polish philosophy, particularly some selected trends, e.g. phenomenology, neo-Thomism, scientific philosophy. He studies practical application of philosophy in coaching.

it is one of the criteria distinguishing philosophy from exact sciences. ${ }^{2}$ Beyond the shadow of a doubt reckoned among these can be Aristotle, Gottfried W. Leibniz or, to name a contemporary, Martin Heidegger. In the opinion of some philosophers in life sciences such questions are not posed, because these sciences limit themselves to only answering the question of "how." 3 The "why" question is regarded as crucial especially

1 "DIÁ TÍ (gr. ঠıá tí - where-fore?; in Latin: propter quid - owing to what?) - a science-forming question in the classical (Platonic-Aristotelian) theory of science" (M. A. Krąpiec, DIÁ TÍ, http:// www.ptta. pl/pef/pdf/d/diati.pdf [30.01.2018]).

2 See J. Pelc, O poznawczej roli pytań, in: Prace z pragmatyki, semantyki i metodologii semiotyki, ed. J. Pelc, Wrocław 1991, pp. 191-200.

3 See S. Kamiński, Jak filozofować. Studia z metodologii filozofii klasycznej, Lublin 1989, passim; M. A. Krąpiec, Metafizyka. Zarys teorii bytu, Lublin 1994, passim. 
for theistically-oriented metaphysics. ${ }^{4}$ Attempts at elaborating it and demonstrating its key role in the metaphysical discourse are constantly made. ${ }^{5}$ Elimination of this question from philosophy is considered to be a manifestation of nonchalance and a lack of understanding of the essence of philosophical cognition. Many theoreticians discern that replacing the "why" question with the "how" question gave rise to a major philosophical crisis and to the emergence of minimalist attitudes (e.g. Kamiński). Elimination of this question followed from the tendencies to make knowledge practical, and only the answer to the "how" question provides a possibility of getting to know facts and the relations between them. Thomists believe that it is the metaphysical, and not semiotic approach that is still of fundamental significance in solving philosophical problems, because semiotics reveals only some of the aspects of this question, focusing attention on its logical form and omitting its relation with the theory of being. ${ }^{6}$ A proper way of posing this question is only possible with the presupposition about the realist theory of being. ${ }^{7}$ Different philosophical concepts interpret this question differently. Currently, in Poland the semiotic approach in the study of this question is prevalent. ${ }^{8}$ Classical philosophers think that the "why" question is the most

4 See W. Stróżewski, Istnienie i sens, Kraków 1994, passim; W. Stróżewski, O zasadnicze pytanie metafizyki, „Znak” 17 (1965) no. 127, pp. 3-23.

5 See J. Wojtysiak, „Dlaczego istnieje raczej coś niż nic?” Analiza problemu w kontekście dyskusji we współczesnej filozofii analitycznej, Lublin 2008, passim; J. Wojtysiak, O zasadzie racji dostatecznej, „Roczniki Filozoficzne” 54 (2006) no. 1, pp. 179-216; A. Brożek, Pytania i odpowiedzi. Tło filozoficzne, teoria, zastosowania praktyczne, Warszawa 2007, passim.

6 See M. A. Krąpiec, O rozumienie filozofii, Lublin 1995, passim.

7 See A. B. Stępień, Wprowadzenie do metafizyki, Kraków 1964, passim.

8 L. Koj, Analiza pytań I. Problem terminów pierwotnych logiki pytań, in: Studia semiotycz$n e$, ed. and a foreword by J. Pelc, vol. 2, 1971, pp. 99-113; L. Koj, Analiza pytań II. Rozważania nad struktura pytań, in: Studia semiotyczne, vol. 3, 1973 pp. 22-39. Of the most recent works noteworthy are: A. Wiśniewski, The Posing of Questions: Logical Foundations of Erotetic Inferences, DordrechtBoston-London 1995, passim; A. Brożek, O pytaniach filozoficznych i ich rozstrzygalności, „Studia Philosophiae Christianae" 45 (2009) no. 1, pp. 7-25, O pojęciach rozstrzygalności i nierozstrzygalności w świetle teorii pytań, in: Філософсвкі проблеми науки / Filozoficzne problemy nauki, ed. A. Brożek, Львів-Warszawa 2008, pp. 355-363. This area also includes J. Wojtysiak's semiotic works on the issues concerned with questions. 
fundamental question for man (e.g. Krąpiec). ${ }^{9}$ Already children spontaneously pose this question to the world. ${ }^{10}$ Man poses this question primarily because the reality he experiences appears to be incomprehensible. ${ }^{11}$ It conveys the basic need to learn and understand the world, which - as the Stagirite was right in diagnosing - is specific to every man. This question provides a foundation for other questions, e.g. answering the question of "how" is predicated on the answer to the question of "why."12

Philosophers very seldom undertake to analyse the "why" question from the perspective of ontogenesis. They believe it to be the preserve of psychologists. Also, many claim that at its starting point philosophy is autonomous and so it does not have to use psychological data, because it can single-handedly reach findings that are no less important than the ones achieved in psychology. This, however, by no means implies that the results of psychological research are deprecated. Existential Thomists themselves, in a more or less conscious manner, brush past the

9 In a sense this paper is a debate with the views held by Thomist authors. It is another part of the dispute between different paradigms. While this paper lays less emphasis on the comparative element (with no direct juxtaposition of various theoretical approaches to the "why" question), giving more space to a systematic approach to the problem, methodologically it fits in with the discourse of the classical aporetic philosophy, which confronts various positions with one another classical with contemporary ones - with a view to discovering new problematic situations and suggesting new, controversial solutions, as no other are possible in philosophy.

10 The "why" question is thus the leading and primordial question-key that opens up the rationality field resulting from the understanding of being and ontic relationships, which, being real, can only be read by the intellect, and not by the senses. The original theory of scientific cognition, which the human intellect engages in, is open to the reading out and understanding of the whole ontic field within the confines of removing absurdity from that field, that is the contradiction that kills acts of cognition (M. A. Krąpiec, DIÁ TÍ, op. cit.). Let me just note that in his works the author very often uses the metaphor of "reading out" of the structure of being.

11 See S. Szuman, Rozwój pytań dziecka. Badania nad rozwojem umysłowości dziecka na tle jego pytań, in: Studia nad rozwojem psychicznym dziecka, selected and prepared by M. Przetacznikowa, G. Makiełło-Jarża, Warszawa 1985, pp. 274-321; S. Szuman, Rozwój pytań dziecka. Badania nad rozwojem umysłowości dziecka na tle jego pytań, Warszawa 1939, passim. A more recent perspective that I have drawn on is: Psycholingwistyka, ed. J. B. Gleason, B. N. Ratner, trans. J. Bobryk, Gdańsk 2005, Chapter 8 is of particular significance for our investigations.

12 M. A. Krąpiec, Filozofia co wyjaśnia, Lublin 1999, pp. 37-38. 
ontogenesis of questions when they claim that, for instance, such questions are spontaneously asked by children, or that they are not taught such questions, and that it is the real world itself that enforces formulation of such questions on them. All these are theses that concern the ontogenesis of questions. Apart from these statements the ontogenesis of metaphysical questions is not explored any further. Philosophers who tend to focus on getting to know the already fully-fledged subject are less interested in the genetic aspect of cognition, which does not help with obtaining the integral picture.

We intend to follow the issue concerned with the ontogenesis of the "why" question in the present analyses, choosing Jean Piaget, a renowned developmental psychologist and the author of genetic epistemology, to be our guide. ${ }^{13}$ It appears that many of his findings still remain theoretically valid. Genetic epistemology, which views human cognition as the dynamic process of the accretion of increasingly complicated cognitive actions and operations, draws on developmental psychology results for its findings. ${ }^{14}$ Hence it is not a methodologically autonomous discipline. It is interdisciplinary, because in explaining cognition it refers to many sciences, additionally subjecting its results to empirical control. ${ }^{15}$ However, it is far from a speculative approach characteristic of traditional epistemology. It also distances itself from providing definitive answers with regard to cognitive actions and operations. By referring to Piaget's

13 See J. Piaget, Psychologia i epistemologia, trans. Z. Zakrzewska, Warszawa 1977; J. Piaget, Mowa i myślenie dziecka, trans. J. Kołudzka, Warszawa 2005; M. Kielar-Turska, Przedmowa, in: Mowa i myślenie dziecka, trans. J. Kołudzka, Warszawa 2005, passim; J. Piaget, Jak dziecko wyobraża sobie świat, trans. M. Gawlik, Warszawa 2006. The noteworthy research papers include: K. Zamiara, Epistemologia genetyczna Piageta a społeczny rozwój nauki, Warszawa-Poznań 1979; K. Zamiara, Epistemologiczne założenia psychologicznej wizji człowieka, in: Materiały XXVI Zjazdu PTP, Szczecin 1987, ed. E. Aranowska, Warszawa 1991, M. Kielar-Turska, Średnie dzieciństwo. Wiek przedszkolny, in: Psychologia rozwoju człowieka. Podręcznik akademicki, ed. J. Trempała, Warszawa 2011, passim.

${ }_{14}$ In the present paper I omit to present genetic epistemology in detail, as this would go well beyond the compass of the delineated analyses. For that matter I refer the reader to Krysyna Zamiara's metatheoretical works.

15 J. Piaget, Psychologia i epistemologia, op. cit., pp. 15-42; K. Zamiara, Obecność myślenia psychologicznego w epistemologii, in: Rozprawy i szkice z filozofi i metodologii nauk, ed. J. Such, WarszawaPoznań 1992, pp. 38-52. 
ground-breaking works, we will first undertake a hermeneutic reconstruction ${ }^{16}$ of the ontogenesis of the "why" question, and then we will try to formulate philosophical implications resulting from this concept. ${ }^{17}$ What can a philosopher with a maximalist attitude to studying reality learn from Piaget? ${ }^{18}$

\section{The ontogenesis of the "why" questions according to Jean Piaget}

Piaget was a psychologist who was not interested in speculation but fact. As he studied the development of child logic, he would always try to rely on facts which to varying degrees corroborated his hypotheses. As he observed - personally or with the help of his collaborators - children in various stages of life, he recorded a number of various types of their questions which he tried to classify, taking into account both formal and material (substantive $)^{19}$ criteria. He considered the material criterion to be the priority. He also used this criterion to classify the "why" questions on account of the fact that with the form alone we cannot tell what type of a cause the child is inquiring about. On the basis of this criterion he concluded that "there are three big groups of children's 'whys' - the 'whys' of causal explanation (including finalistic explanation), those of motivation, and those of justification. Inside each group further shades of difference may be distinguished. After a certain age (from 7 to 8 onwards) there are also the whys of logical justification." ${ }^{20}$ The latter ones appear in child's ontogenesis the latest. The term "explanation" refers to either

16 It is about hermeneutic analysis. See H. H. Krüger, Wprowadzenie w teorie i metody badawcze nauk o wychowaniu, trans. D. Sztobryn, compiled by B. Śliwerski, Gdańsk 2005, pp. 146-147. Let me stress that this is not a complete reconstruction of ontogenesis. I draw attention to only those aspects of Piaget's concept which are necessary while discussing the status and role of the "why" question.

17 These implications should not be treated as necessary statements, but rather as hypotheses which of course can be rejected in the presence of other assumptions.

18 The implications derived will thus concern not only the structure of cognition, but also the structure of philosophical theory. Hence, all of them are metatheoretical.

19 J. Piaget, Mowa i myślenie dziecka, op. cit., pp. 150-155.

20 J. Piaget, The Language and Thought of the Child, trans. Marjorie Warden, London 1926, p. 166. 
logical explanation, which consists in a deductive association of certain propositions, or to explanation that takes into consideration efficient, final causes or psychological motivations. There are also "whys" concerned with a variety of social rules and norms which the child encounters in the course of socialisation. They are akin to questions concerned with motivations. A child very often asks about the motive behind the acceptance of some rule or norm, or, when he is older, about the logical reason for recognition of a given rule or norm as valid. ${ }^{21}$ However, in view of children's ambiguous perception of the cause, it is necessary, when classifying questions, to take into consideration the material criterion directing attention to the objects that the child is inquiring about. Piaget also does not take into account children's questions specific to the egocentric stage. He finds them to be pseudo-questions. In such a kind of attitude the child poses a question to himself, and even if he does it in the context of adults, he does not require any answer of them. This also applies to "dialogues" acted out in the egocentric attitude between age peers. Also in this context the questions posed do not presuppose any intention of obtaining information from other children. In essence, passive echoing of adults' questions is the first ontogenetic step in learning them. The child imitates adults without understanding the meaning of the interrogative sentences he utters. A child, who is an egocentric, cannot confront his thoughts and questions with other people, nor can he objectivise his thinking, which is always connected with depersonalisation and attempted adoption of the viewpoint of others. ${ }^{22}$

The ontogenesis of children's 'whys' begins around the age of 3.

Until around the age of 7 there is some kind of hypertrophy of questions put to adults by children. However, the "why" question is not a child's primal question. More fundamental questions posed by children are the ones about the location of objects, or about their names. A child frequently asks "what is this," demanding that an adult provide him the name of a given object. The first 'whys' asked by children follow from

${ }^{21}$ See J. Piaget, Mowa i myślenie dziecka, op. cit., p. 154.

22 See J. Piaget, Mowa i myślenie dziecka, op. cit., p. 206. 
anxiety and emotional rather than intellectual curiosity. ${ }^{23}$ A child gradually passes from this emotional curiosity about the world to intellectual curiosity, which comes to be expressed in the formulation of more and more sophisticated questions. Asking the "why" questions, which takes place around the age of 3 , is linked with the formation of various planes of reality. Piaget explains that the point is that "up till the age of 3 , the real may be said to be simply what is desired. There is, indeed, after 1 or 2 a yes and a no, a real and an unreal, but without any further shade of difference. At about 3, on the other hand, the imagined is something distinct from the real." ${ }^{24}$ The emergence of the "why" questions is therefore related to a child's new experience of reality. Until the age of 3 a child experiences conformity of his desires and wishes with reality. Then comes the experience of growing resistance from the world. In a child's experience his needs and wishes do not conform with the reality of things and adults. Gradually, he begins to distinguish the world immediately accessible in perception from something that precedes all occurrences, and which acts as their constant substratum. That thing is intention. It arises as a result of the resistance that a child experiences as put up by reality. ${ }^{25}$ A child begins seeing all phenomena and occurrences as possessing intentions, purposefulness, some internal forces affecting them. Thus, a child's world becomes populated with intentions attributed to things and other persons. ${ }^{26}$ "It is these intentions ascribed to people and to things which will give rise to the types of question corresponding to the principal categories of child thought. These categories will therefore have an intentionalistic origin, i.e., they will arise from the conscious realization of psychological operations relative to intentions, and not from a mere observation of the world given in perception. Moreover, the earlier categories of name and place, etc., will join themselves to these categories of intention, and together with them will form a single whole." ${ }^{27}$

${ }^{23}$ See J. Piaget, Mowa i myślenie dziecka, op. cit., p. 152.

24 J. Piaget, The Language and Thought of the Child, op. cit., p. 231.

${ }_{25}$ See J. Piaget, Mowa i myślenie dziecka, op. cit., p. 204.

26 See J. Piaget, Mowa i myślenie dziecka, op. cit., pp. 202-203.

27 J. Piaget, The Language and Thought of the Child, op. cit., p. 234. 
Thus, the first "why" questions formulated by children first and foremost concern intentions underlying an action or an occurrence. The first 'why' asked by a child therefore refers to human actions.

The "why" questions relate to various types of causality. Before a child acquires an ability to use the notion of cause, he treats himself as a cause initiating many actions. Obviously, he does not realise that, which still justifies speaking about causality irrespective of the degree of conscious realisation. ${ }^{28}$ Conscious realisation of causality forms gradually along with the development of actions and mental operations, and leads to distinguishing various types of causality, such as: animistic, finalistic, mechanistic, dynamic, etc. Therefore, causality does not follow from perceptions. It is not an effect of some simple abstract generalisation. It is a dynamic category which passes through its stages of becoming manifest in the course of ontogenesis, which results in some types of causality yielding to others, e.g. animistic causality gradually yields ground to mechanistic causality based on spatial contact between objects.

The first "why" questions about causality do not, however, refer to mechanistic causality. At this stage a child cannot think in terms of causality, which is about spatial contact between objects. As he asks "why," he is looking for forces and intentions underlying objects and occurrences. Most questions are posed with regard to animate beings, and statistically fewer questions relate to inanimate objects. To a child, who ascribes intentions and forces to objects and persons, there is no room for chance in the world. It is a whole of closely interrelated occurrences and situations. Everything happens out of some necessity. As Piaget writes, "a world in which chance does not exist is a far less mechanical and far more anthropomorphic a world than ours." ${ }^{29}$ Agnosticism of everyday life, ${ }^{30}$ which is connected with the introduction of the category of chance, appears later on, when a child discovers the fact of death. To an adult, who uses the

28 See J. Piaget, Mowa i myślenie dziecka, op. cit., p. 200.

29 J. Piaget, The Language and Thought of the Child, op. cit., p. 174.

30 The point here is that some attitude arises when the cognisant subject realises that there is room for chance in the world, that not everything is purposefully organised, that some phenomena are unknowable and their occurrence is impossible to be anticipated. 
notion of mechanistic causality, in the world there is room for chance consisting in mutually independent causal chains intersecting one another. Between the years of 7 and 8 a child cannot use the notion of causation of this type. Causality is of a purposeful character and is more concerned with psychological motivation. It does not have a character of spatial contact between two objects. Piaget even goes as far as to say that what we are dealing with at this stage is not so much causality as precausality. $\mathrm{He}$ claims that "we shall designate by the name of precausality this primitive relation in which causation still bears the marks of a quasi-psychological motivation. One of the forms taken by this precausality is the anthropomorphic explanation of nature. In this case, the causes of phenomena are always confused with the intentions of the Creator or with those of men, who are the makers of mountains and rivers. But even if no 'intention' can be detected in this anthropomorphic form, the 'reason' which the child tries to give for phenomena is far more in the nature of a utilitarian reason or of a motive than of spatial contact." ${ }^{31}$ This precausality is conditioned by a child's "intellectual realism." A child constantly tends to supplement that which he sees with thought. The reality he experiences is much more of a construct of his than a product provided by pure observation. In this sense, a child's realism is not a visual realism but an intellectual one. If we observe a child less than 7 years of age, then we are "struck by the extent to which his vision is distorted by his ideas." 32 That is why a child does not look for explanations based on mechanistic causality (spatial contact), but in keeping with intellectual realism he seeks motivations and intentions (finalism) in phenomena and occurrences. The explanations provided by a child are not characterised by logical deduction. "For the child, an event leading to an event, a motive leading to an action, and an idea leading to an idea are all one and the same thing; or rather, the physical world is still confused with the intellectual or psychical world." ${ }^{33}$ In this period a child evinces an all-encompassing tendency to justify everything. And in this

31 J. Piaget, The Language and Thought of the Child, op. cit., p. 181.

32 J. Piaget, The Language and Thought of the Child, op. cit., p. 183.

33 J. Piaget, The Language and Thought of the Child, op. cit., p. 184. 
he is different from adults, who first accept the existence of chance, and second believe that some things and occurrences cannot be explained. A child rejects that which in experience is given as accidental, unrelated or simply chaotic. In the attitude of intellectual realism "the child cannot grasp the idea of the 'given', and he refuses to admit that experience contains fortuitous concurrences which simply happen without being accounted for. Thus, there is in the child a tendency towards justification at all costs, a spontaneous belief that everything is connected with everything else, and that everything can be explained by everything else. Such a mentality necessarily involves a use of causality which is other than mechanical, which tends to justification as much as to explanation, and thus once more gives rise to the notion of precausality." ${ }^{34}$

The tendency to explain everything by everything else is based on syncretism. Under the age of 7 a child's perception and intelligence are essentially syncretic. Intellectual realism and syncretism in perception and thinking are interrelated. ${ }^{35}$ Syncretism in thinking (verbal intelligence) and in perception (perceptual intelligence) in the child consist in referring to general analogous schemas of a perceptual and notional character. Application of these schemas involves understanding of diverse parts. Schemas are typically of an indefinite and hardly analytic character, which facilitates combining them into a more or less coherent wholes. A child's perception is syncretic, comprehensive and does not focus on decoding details. Consequently, the child does not discern nuances required, for instance, to comprehend the spatial contact between objects, which is specific to mechanistic causality. A child cannot adjust to details. As Piaget claims, syncretic perception in a sense compels the child to connect a thing with a thought itself. Connecting everything with everything is for him (the stage of 5-6 years of age) a matter of necessity. The sense of necessity precedes all explanation. That is why the answer to the "why" questions posed by children might as well be "because it must be so." However, as he observes and catalogues children's questions, Piaget

\footnotetext{
34 J. Piaget, The Language and Thought of the Child, op. cit., p. 184.

35 See J. Piaget, Mowa i myślenie dziecka, op. cit., p. 167.
} 
notes that "as a general rule... the child confuses human necessity (moral and social, the 'decus') with physical necessity. (The idea of law has long retained the traces of this complex origin). A great many of the 'whys' of children, therefore, do no more than appeal to this feeling of necessity [...]. The connexion will now be seen between this type of explanation and precausality, which is precisely the result of a confusion between the psychical or intellectual world, or the world of ethical or logical necessity and the world of mechanical necessity." ${ }^{36}$

Piaget also notes that thinking in terms of the categories of precausality and intellectual realism is conditioned by primitive egocentrism. For a long time it stands in the way of the child moving up to the level of objective (intersubjective) thinking, which is always connected with confronting one's thoughts with others, which has its origins in asking questions like: "what is this?," "where is it?," why is that so?" The more the child is focused on his own Self, the less capable he is of becoming free from animistic beliefs, from treating all things and phenomena in terms of intentions and underlying forces which affect their emergence. "We can now see that ego-centrism, while it does not exactly explain the child's incapacity for true causal explanation and logical justification, is nevertheless closely connected with it. And we can understand how, as a result of this, the child's mind is always hovering between these two convergent paths, and is also equally removed from both. This it is that gives rise to the phenomena of precausality and intellectual realism, both of which bear witness to this intermediate position. And this it is also that gives rise to that tendency in children to justify things at any price, or to connect everything with everything else." ${ }^{37}$

In fact, between the ages of 3 and 7 a child asks about everything. As he adopts the attitude of intellectual realism, his thinking and perception being syncretic, he consequently apprehends everything that he experiences in the categories of animistic, artificial and psychological causality. However, in the course of ontogenesis, the notion of precausality

36 J. Piaget, The Language and Thought of the Child, op. cit., p. 187-188.

37 J. Piaget, The Language and Thought of the Child, op. cit., p. 238. 
gradually disappears. The questions asked by children (aged 7-8) more and more frequently feature a pure notion of causation related to mechanistic causality. More and more often, the child pays attention to the details of various things, and learns to discern the spatial contact between them. The relative number of "why" questions decreases, giving more and more way to emerging questions concerned with reality and history as well as logical explanation. "In logical justification, thought becomes conscious of its own independence, of its possible mistakes, and of its conventions, it no longer seeks to justify the things in themselves, but its own personal judgements about them. Such a process as this appears late in the psychological evolution of the child." ${ }^{38}$ It probably takes place around the age of 7 or 8 , which is connected with the gradual disappearance of animistic thinking. The gradual disappearance of the "why" questions results from the fact that a child begins to ask completely different questions that are supposed to supplement his knowledge. Answers to the "why" questions typically provide general knowledge. But the child evinces a constant and unbridled need to acquire specific knowledge which satisfies the requirements of logical justification and coherence. Apart from questions about the reality of events and their history, the child also poses questions about rules, which are to an ever greater extent liberated from the pressure of anthropomorphic and psychological ideas. As regards rules, he inquires about the logical justification of their applicability. The child also begins to ask more questions concerned with counting and classification of the surrounding objects. He inquires not only about the name of a given object, but also about its definition useful in understanding it. In Piaget's opinion, the questions about rules, names and definitions are normative questions. ${ }^{39}$ The noticeably declining number of questions concerned with precausality is related to the gradual disappearance of ego-centric thinking. Ego-centrism, which to a greater degree obeys the logic of personal whims and desires, may

38 J. Piaget, The Language and Thought of the Child, op. cit., p. 194.

39 See J. Piaget, Mowa i myślenie dziecka, op. cit., pp. 183-190. 
for a long time hold the child captive, acting as a direct obstacle to the achievement of logical systematisation and depersonalised thinking. ${ }^{40}$

One of the ways to verify the decrease in thinking in terms of precausality is to ask a child some questions which he formulated before the age of 7 . When you ask a child over the age 7 questions which he asked at 6 or 7 , he expresses surprise and sometimes also confusion. In a situation like this he tends to correct the adult, saying that such questions should not be asked, because they are nonsensical, or he provides answers that take into account mechanistic causality or logical justification relating to specific inferential relationships between judgements. Piaget was painstaking about recording and systematising, according to the material criterion, questions asked by a child named Del. He concluded that the notion of precausality used by Del was becoming increasingly varied, which was connected with the gradual replacement of mechanistic causality with quest for logical justifications. He also observed that the receding of precausality is connected with the vanishing of anthropomorphic and artificialistic thinking. He writes as follows: "There is, therefore, a complete discord between the questions asked by Del and the manner in which he answers them a few months later, and this seems to indicate that the child has partly given up the use of precausal explanations. The questions were originally put as though a precausal explanation were possible, as though everything in nature could be accounted for, as though everything were animated by intentions, so that the looked-for cause of phenomena could be identified." ${ }^{41}$ The answers given by Del did not take into account the notion of precausality. This was related to the fact that in his mind there appeared correct distinctions between different types of causation linking objects. This does not, however, mean that in the period in question the child has already acquired a pure notion of mechanistic causation or logical justification. For a much longer period of ontogenesis this justification will continue to be mixed up with psychological justification. Only at an older age (11-12 years) do causal explanation and logical justification

\footnotetext{
40 See J. Piaget, Mowa i myślenie dziecka, op. cit., p. 206.

${ }^{41}$ See J. Piaget, The Language and Thought of the Child, op. cit., p. 225.
} 
become "pure," that is without the admixture of the looked-for psychological motivation.

As Piaget emphasises, the "why" questions involve three functions:

explicatory, implicatory and mixed. ${ }^{42}$ These functions are dynamic. At first they appear to be in some state of undifferentiation. It is only in the course of ontogenesis that they gradually develop and gain independence, turning into functions linked with the increasingly complex actions and reversible cognitive operations. At the beginning of ontogenesis the explicatory function is the most dominant one. This results from the need that the child is experiencing when he realises the existence of the intention arising under the influence of the resistance caused by the discrepancy between desires and things. Then he feels the need to attribute those intentions to other objects and persons whose resistance he is experiencing. This function has two poles: psychological explanation and material explanation. In the initial period of ontogenesis these poles overlap. Only in later stages do they gradually diverge. ${ }^{43}$ This function is oriented towards the outside world. It is directed at reality, time, place and causality. Originally, the implicatory function arises in response to the child seeking underlying intentions and forces in objects. This function too has two poles; one is psychological and the other is concerned with names, classifications, that is logical justification. Thus, the implicatory function is directed not at things, but intentions, motives and ideas. In the course of ontogenesis this function in a sense becomes specialised and begins to play an ever greater role in thinking, which gradually leaves behind the stage of precausality. In its fully-developed form the implicatory function is specific to logical justification. Then, it turns to classification, name-giving, capturing specific logical relations between judgements. The question about names and definitions is connected with the implicatory function. To an ever-decreasing extent it is concerned with real things (the explicatory function), and to an ever-increasing extent it is concerned with notions and definitions that depend on them.

42 See J. Piaget, Mowa i myślenie dziecka, op. cit., pp. 203-204.

${ }^{43}$ See J. Piaget, Mowa i myślenie dziecka, op. cit., p. 204. 
This is because logical justification is about focusing on the relations between statements, and not things. At this stage the child can capture the independence of a thought and a thing. The explicatory and implicatory functions can also take the form of a mixed function, which turns to the motivation of actions as well as justification of rules and norms, which the child encounters in the course of social development. As these functions develop and become differentiated, so do the child's questions with regard to their substance, which is pointed to by the paradoxical fact that "child thought is equally removed from dealing with strictly causal explanation as it is from dealing with logical justification properly so-called. The whole mechanism of children's questions, as we have studied it, can be accounted for by this fundamental fact." ${ }^{44}$

\section{The philosophical implications of the ontogenesis of the "why" question}

(1) The ontogenesis of the "why" questions provides a number of interesting implications which, on the one hand, confirm, while the other hand question a number of theses propounded by, for instance, Thomist metaphysicists. It is worthwhile drawing attention to several metatheoretical issues connected with this. At first, one should remember that no explicit philosophical implications result directly from the ontogenesis of questions itself. If we speak about them, then only as some interpretative consequences. ${ }^{45}$ And each one of these interpretations is always relativised to a specific philosophical hermeneutic. ${ }^{46}$ Hence, the implications

44 J. Piaget, The Language and Thought of the Child, op. cit., p. 237.

45 See J. Woleński, W stronę logiki, Kraków 1996, passim; J. Turek, Filozoficzne interpretacje faktów naukowych, Lublin 2009, passim; J. Turek, Implikacje ontologiczne typu redukcyjnego jako metoda uprawiania filozofii przez Księdza Profesora Kazimierza Kłósaka, in: Filozofia a nauka w myśli Księdza Kazimierza Kłósaka, ed. Z. Liana, A. Michalik, Kraków-Tarnów 2004, pp. 63-88; Z. Hajduk, Filozofia przyrody - Filozofia przyrodoznawstwa. Metakosmologia, Lublin 2004, passim. I write about the problems of interpretation of scientific facts in greater detail in: P. Duchliński, $W$ stronę aporetycznej filozofii klasycznej, Kraków 2014.

${ }^{46}$ See J. Woleński, W stronę logiki, op. cit., passim; J. Woleński, Logika, kontekst odkrycia, kontekst uzasadniania, in: Odkrycie naukowe i inne zagadnienia współczesnej filozofii i nauki. Pamięci 
derived will not, perforce, be shared by many philosophers, especially those who defend the epistemological autonomy of philosophy in relation to empirical sciences, and who at the starting point voice necessary statements, distancing themselves from any hypotheses. ${ }^{47}$ Undoubtedly, Piaget's genetic epistemology is a science firmly embedded in the empirical data of developmental psychology. ${ }^{48}$ Still, one needs to remember that Piaget's goal was epistemological, for he was striving to answer the question of "how is cognition possible?" ${ }^{49}$ In order to answer this question one needs to follow the way cognition gradually develops, the way the human mind acquires certain categories and structures that enable it to experience the real world in the way it does. Piaget was critical of all speculative metaphysics of cognition, as he did not believe that it was impossible to pursue epistemology which could not legitimise its results in the form of theoretically encapsulated empirical experience. His research was done with a view to accomplishing specified epistemological goals. In all this discussion the crucial thing is that the implications derived from ontogenesis come to be test-proven in the empirical facts concerned with the development of cognitive structures. ${ }^{50}$ It appears then

Elżbiety Pietruskiej-Madej i Jana Żytkowa, ed. W. Krajewski, W. Strawiński, Warszawa 2003, pp. 75 87; J. Woleński, O tak zwanych filozoficznych założeniach nauki, in: Z zagadnień filozofii nauk przyrodniczych, ed. S. Butryma, Warszawa 1991, pp. 7-16.

47 At the starting point for philosophical inquiry it is worth using the proposition formulated by Heller. It is a non-foundationalist strategy. "I am inclined - writes Heller - to regard critical discussion as a crucial element in the method which I have called a «method of loops», provided the method is employed in philosophy [...] It is not an easy postulate, because every debate (and especially one with a real opponent) triggers some psychological mechanisms of defence and aggression. To be able to oppose them from the very beginning, it is worthwhile couching one's views (even if they are best-founded) not in the form of categorical statements, but hypotheses that allow enough leeway for modification or reformulation. But a philosopher's work does not end with a formulation of a hypothesis. The hypothesis comes to be included in the «non-linear cycle of thought». Philosophy is not about reaching conclusions that are then filed away and forgotten" (M. Heller, Przeciw fundacjonizmowi, in: M. Heller, Filozofia i Wszechświat, Kraków 2006, p. 100).

48 See A. Bronk, Demarkacjonizm lubelskiej szkoły filozoficznej, „Roczniki Filozoficzne” 35 (1987) bull. 1, pp. 345-364.

49 J. Piaget, Psychologia i epistemologia, op. cit., p. 15.

50 See J. Życiński, Zagadnienie możliwości falsyfikacji twierdzeń w filozofii przyrody, „Analecta Cracoviensia” 14 (1982), pp. 94-98. The author cites examples from philosophy of nature. 
that in this way it can be shown how philosophical theses (of Thomistic metaphysics) can be corroborated or negatively tested by ontogenetic data. The example of questions is very meaningful here, because both philosophers and psychologists believe that questions play quite a significant role in cognition of the world and man. ${ }^{51}$ Underlying the positive approach to philosophical implications of ontogenesis is the premise that philosophy can substantially benefit from the results of empirical science research. They can be a precious complement to semantic and ontological analyses, and result in correction of a number of exotic propositions regarded by some philosophers as definitively true or uncorrectable. This obviously presupposes a concept of philosophy which is at least partly open to the results of various exact sciences. ${ }^{52}$ However, without any exaggerated fear that such a philosophy might lose its epistemological and methodological status.

(2) The results of ontogenetic research certainly prove that children ask "why" questions in a spontaneous way and under the influence of the things or other persons' actions that they experience. Besides, they validate the thesis, so frequently propounded by philosophers, whereby it is from childhood that man seeks information which is necessary not only to understand the world, but also to be able to effectively adjust to it. With the benefit of the ontogenesis of questions we obtain a dynamic picture of human knowledge and cognition. Cognition is a process which over the course of years gets complicated, which can be proven by the accretion of new cognitive actions and operations. Many contemporary authors strongly emphasise this dynamic of cognition, even though many still

51 See R. Radwiłowicz, O pytaniach uczniowskich ogólnie, in: Pytania uczniów a treść nauczania, ed. R. Radwiłowicz, K. Pauzewicz, C. Kosiński, Warszawa 1969, passim; R. Fisher, Stawianie pytań, in: R. Fisher, Uczymy jak uczyć, Warszawa 1999, passim.

52 "The crux of the matter is that propositions including a hermeneutic factor can be elucidated in a manner understandable to persons using different hermeneutic systems, or hermeneutics in short, whereby they acquire an intersubjectively communicable meaning, while they do not need to become empirically verifiable. Arguably one is allowed to say that they become somehow verifiable with regard to their hermeneutic content, but as I have stressed before, it is a matter of secondary importance. In essence, it is about the question of understanding" (J. Woleński, Sens i nonsens w filozofii, in: J. Woleński, W stronę logiki, op. cit., p. 350). 
follow the well-trodden path of traditional approaches, viewing cognition in a "frozen" manner.

(3) The ontogenesis of questions also implies sceptical conclusions concerning the ideal of disinterested cognition. It is about such a type of cognition whereby we perform specific cognitive actions for their own sake only, and not because of some outside pragmatic or utilitarian goals. One might wonder when and at what point in his life man asks questions expressive of his cognitive disinterestedness. From the perspective of ontogenesis, a child inquires about names of objects or their location only to be able to use them more capably. Here, cognition is subservient to other goals, e.g. better adaptation to the surroundings or proper execution of instructions issued by adults. As Piaget shows, a child's primitive goals are typically utilitarian. And that is a completely adequate and normal situation from the developmental viewpoint. A small child does not inquire for the sake of inquiring, unless he is at a very early stage of ontogenesis, when he only repeats after the adults certain sounds the meaning of which he can hardly comprehend, or when he is in some morbid state displaying, e.g., some compulsive behaviour the symptoms of which can be notorious questioning without any clear communication-related goal. The problem of how to understand disinterested cognition arises. Disinterested with regard to whom? If cognition is related to some object, then it must always involve some interest in the object. If there were no moment of interest, then we could not perform any cognitive actions. Why would we want to become cognisant of anything, if we were not interested in it in the first place? But man, as the subject of cognition, asks a great many questions and he always does that for specific purposes. Even if those are only theoretical purposes devoid of practical reference, he never does that out of purely cognitive necessity, for such kinds of isolated necessity do not exist, but because of definite intentions and practical motives deeply set in his mind. As we ask "why," we are looking for specific information which will not only satisfy our need for knowledge, but will also contribute to the achievement of greater mental and emotional comfort, the lack of which generates this type of questions in the first place. The ideal of disinterested cognition has a character of an 
abstract postulate which is far removed from the way in which people really perceive reality. Ontogenesis does philosophy no mean favour by showing that asking questions is never conditioned by some disinterestedness, but by interest in specific objects of questions (interest in the real world). If there were no interest of this kind, which does not have to be purely utilitarian, a question would never be asked.

(4) Ontogenetic data may challenge some philosophical theses.

For instance, according to Thomist metaphysicists a child asks "why," because he wants to understand the ontic structure of things. However, with the benefit of ontogenesis we know that children ask this question not for intellectual reasons, but as a result of emotional motivation which is expressed by surprise and confusion. Moreover, one can hardly accept the theses whereby all questions are reducible to or grounded in the "why" question. The study of children's questions provides an opposite thesis. The "why" question is not a basis for other questions. Nor can other questions be reduced to it. On the contrary, this question needs to be supplemented or replaced with other questions. Answers to the "why" questions provide general knowledge, which calls for particularisation by means of formulating further questions. Besides, it is hard to get a handle on the postulated reduction of all questions to the "why" question, which is put forth by some, e.g. Thomist authors. We do not know whether the reduction is supposed to be semiotic, epistemological or of some other kind. The sense of this reduction is usually not explained (e.g. Krąpiec). Given ontogenesis, we can conclude that the "why" question by no means determines the cognitive development, i.e., its hypertrophy occurs only within a specified period of development, which gradually grows smaller, giving ground to other types of questions, which are, from the ontogenetic viewpoint, no less important than the "why" question. Still, it seems that the so-called categorical questions better contribute to the development of cognition, because they enable acquisition of specific knowledge, which is much more useful for adaptive reasons.

(5) The ontogenesis of questions also gives rise to implications of quite considerable relevance for the understanding of the realism of human cognition. Apparently, we are not realists as loyal to reality as 
we are expected to be by some philosophers, especially realisticallyinclined Thomist metaphysicists. Research on children's early cognitive development proves that a child's realism is not visual, but intellectual. Regularities concerned with a child's perception of reality are discovered on the basis of the analysis of modal questions. To a child, reality is something rather constructed than passively reflected. ${ }^{53}$ Even though a child's thinking is realistic, it is done in the spirit of intellectual realism. A child's suppositions concerned with reality are less stable than the ones of an adult. To us, reality is more stable, definite, and besides an adult can clearly distinguish between thought and reality. He can perform complicated processes of logical justification concerning relationships between judgements and not things. On the one hand, a child finds real reality to be more arbitrary, because it is populated by the world of thoughts considered to be as real as physical objects. On the other hand, a child's world is more stabilised due to the fact that there is no randomness about it. ${ }^{54}$ As regards possibility, it is a certain degree of reality to an adult. But to a child, possibility is no degree of reality, but it is as real as anything else. This shows that we are never realists in the sense that we reflect reality, which strikes our apparatus with the "edge of its being." We never hang on to this reality unwaveringly, not as children, because we embrace the attitude of intellectual realism, and not as adults, for whom thought and reality do not combine in an unambiguous manner. From the viewpoint of ontogenesis of cognition the fact that man can detach himself from reality and only use thoughts is a manifestation of normal development realistically construed. Clinging tightly to things, on the other hand, is an indication of ego-centric thinking, for which the world and thought constitute an undifferentiated whole. Besides, any formal operations that arrive for good between the age of 11 and 12 can be successfully performed only because we are able to detach a thought from a real thing and concentrate on intellectual operations themselves of a reproducible character, e.g. mathematical operations. That is why the

53 See J. Piaget, Mowa i myślenie dziecka, op. cit., p. 165.

54 See J. Piaget, Mowa i myślenie dziecka, op. cit., pp. 186-187. 
choice between acquiring cognition and thinking, which is promoted by Thomists, cannot be, from the viewpoint of ontogenetic data, validated at all. ${ }^{55}$ Acquiring cognition and thinking are so closely intertwined that it would be difficult to pinpoint in a man's development the moment at which he thinks but does not become cognisant, or vice versa. The fact that we can think while becoming detached from things is not an indication of degeneration, but of normal development. Clinical examples of persons with autistic and ego-centric disorders clearly show what happens to a man who constantly remains on the plane of intellectual realism. However, philosophers tend to voice abstract propositions contrary to previously voiced ones, because they do not take into consideration empirical data concerned with children's cognitive development. Piaget aptly sums up this situation: "The child shows signs of a perpetual intellectual realism: he is too much of a realist to be a logician, and too much of an intellectualist to be a pure observer. The physical world and the world of ideas still constitute for him an undifferentiated complex; causality and motivation are still thought of as one and the same. Adults too, with the exception of metaphysicists and naive realists, regard the connexion of events and that of ideas as one, in the sense that logic and reality constitute two series inextricably bound up with each other. But the adult is sufficiently detached from his ego and from his ideas to be an objective observer, and sufficiently detached from external things to be able to reason about assumptions or hypotheses held us such. This brings about a twofold liberation and a twofold adaptation of the mind. The child's ideas, on the other hand, hinder his observations, and his observations hinder his ideas, whence his equal and correlative ignorance of both reality and logic." ${ }^{36}$

Philosophers have a right to put on the "why" question interpretations that follow from their presuppositions. And since each philosopher adopts presuppositions that differ in substance, there are so many

55 See M. A. Krąpiec, Poznawać czy myśleć. Problemy epistemologii tomistycznej, Lublin 2000, passim.

56 J. Piaget, The Language and Thought of the Child, op. cit., p. 214. 
differences in the interpretation of the "why" question occurring between Thomists and followers of Leibniz or Heidegger. Ontogenesis only shows the way logic of such questions develops. But it does not determine their metaphysical interpretation in any way. Thomists often invoke psychology, which in their opinion confirms spontaneous realism as a natural cognitive attitude, thereby reinforcing the conviction that being is the first object of cognition. ${ }^{57}$ Indeed, psychology confirms that realism is a child's natural cognitive attitude, but it is not the kind of realism that Thomist metaphysicists write about. It is not a direct realism connected with the reflection in cognitive processes of things in real existence, but an intellectual (constructive) realism.

(6) With the benefit of ontogenetic data we learn that a child first formulates questions not with regard to things, but actions performed. "The earliest 'whys' are generally asked in connexion with human actions. The first 'why' noted by Scupin in the case of 'Bubi' is of this order. The child's mother was lying on the ground. The boy wants to get her up: «du bist ja nicht tot, warum stehste nicht immersu auf?». The second one appears when the child is forbidden to pull the petals off flowers. «Warum denn?». But even where children begin with a "why of explanation," it is difficult not to see in the expected explanation not only a precausal explanation, but one in which precausality is almost entirely confused with psychological or intentional causality: «Why do trees have leaves?»." ${ }^{28}$ Therefore, real being does not take centre stage of a child's attention. But when it becomes the object of his attention, the child asks "why" questions concerned with animistic or artificialistic causality. He does not originally strive to understand the nature of things with regard to its relations or constitutive factors. Nor does he take into consideration the efficient causes, either external or internal ones. Looking for them appears in time, when the child learns to use the category of mechanistic causation. This shows that our primitive interest in the world is not concerned with

57 Even though it is just one of interpretative hypotheses, Thomists find it to be the definitive interpretation.

${ }^{58}$ J. Piaget, The Language and Thought of the Child op. cit., p. 165. 
understanding of things, but intentions, motives and forces. In the early period of ontogenesis we are not interested in understanding the structure of an object, but in the underlying intentions. That is why finalistic causality takes centre stage. All this is related to the intentional development in a person, who experiences that which is real in the form of resistance against the background of the growing incongruity between his desires and thoughts, and reality. It is against the backdrop of this incongruity that the primitive intentionality of a child's mind is formed and the world begins to be populated with new ontology, which presupposes the existence of underlying intentions and forces which determine various phenomena and objects.

It may be difficult to bring ontogenetic data in objective alignment with statements that read, for instance, as follows: "The question [«why»- P. D.] is a spontaneous question which both children and adults ask when something is not self-evidently understandable - when there are some hidden factors incomprehensible with regard to the state of affairs. The «why» question is essentially connected with the aspect of understanding of a cognisable thing." ${ }^{59}$ The child may look for factors, but ones that primarily concern understanding of human actions, and even if he is looking for them in things, he is out for intentions and underlying forces, and not for analogous relations that constitute the structure of being. The author's statement which has been quoted here shows how interpretations of the experience of the real world, in which questions play a specific role, are performed in philosophy in a highly theorised form.

(7) Many philosophers declare outright that the purpose of philosophical endeavour should be to find the ultimate causes that explain reality (Thomists) This quest for ultimate explanation has had a very long history and is connected with some tendency to construct maximalist philosophical systems, within which everything might be ultimately understood on the basis of some direct data defying any epistemological problematisation. Today this feature of philosophical research has come to be challenged by many philosophical trends. It is being dismissed by

59 M. A. Krąpiec, Filozofia co wyjaśnia, op. cit., p. 37. 
continental philosophers who trace their origins to hermeneutics and postmodernism, as well as by philosophers of science and analysts of every hue. What does this problem look like from the viewpoint of ontogenesis? From the viewpoint of the ontogenesis of cognition, the tendency to find ultimate explanation for everything is a feature typifying thinking displayed by a child aged between 3 and 7 . In that period the child is not capable of using the notion of mechanistic causation or of logical justification. His thinking is overpowered by anthropomorphism and artificialism. The child believes that everything is connected with everything by some kind of necessity. There is no room for chance in a child's world. That is why he looks for explanations that from the viewpoint of older age very often do not make any sense. This is well illustrated by tests demonstrating the disappearance of the notion of precausality in children between the age of 7 and 8 . As mentioned before, in a child's world as yet there is no notion of chance, which appears much later, at the moment when the child discovers the regularities concerned with life and death. The adult world is different. Everything is not connected with everything. There are chance occurrences and circumstances under which the intersecting causal chains are not cognizable. To an adult there are occurrences and situations which cannot be explained, much less explained forcibly and ultimately by referring to factors contrary to the knowledge you possess, or anthropomorphic factors suggestive of underlying forces and intentions in things. But adults can put up with a child's questions, even if from the viewpoint of their knowledge they have no cognitive relevance. The stage of constantly looking for relationships between everything and everything, and explanations based on types of causation mixed up in the child's mind is specific to the stage of ego-centric thinking. With the aid of perception and syncretic thinking the child sees the world as a complex of interlinked phenomena, without paying particular attention to nuances and details. As a result of this, he introduces underlying forces and intentions in place of spatial contact. Might that mean that philosophers who sometimes like obsessed go on seeking for ultimate explanations have not grown out of the stage of egocentric thinking yet? Are they still in the world in which there is no room 
for chance, and where everything is related to everything by some inner necessity? If we literally referred the findings of ontogenesis to philosophical "work," one might conclude that in fact some philosophers are just like "big babies" who try to outshout one another, proving who has got a better explanation of the world. Maybe many will find such observations to be an indication of some misunderstanding testifying to the fact that the author of these words fails to understand what philosophical endeavour is about. However, this sarcastic remark is more about drawing attention to a certain type of psychological mentality which typifies philosophical thinking, rather than about reproaching other philosophers for childish thinking. After all, a mature philosopher who has really got the hang of the research tools of the trade knows very well (or should know) that such ultimate justifications in the sphere of such abstract theories as philosophy cannot be attained without accepting a number of conventional decisions. ${ }^{60}$ Reality alone does not offer any definite ontological or semantic solutions. Nor does it suggest any language game which might perform the role of a universal lexicon providing descriptions of all facts and the relations between them. Regardless of whether philosophers evince a tendency towards ego-centric thinking, it needs to be recognised that ontogenesis furnishes sufficient empirically corroborated evidence that given a properly and normally developed cognitive apparatus ultimate justifications are hardly acceptable. ${ }^{61} \mathrm{On}$

${ }^{60}$ These issues can be explored in greater detail within the framework of the so-called psychology of philosophising, which points to some correlations between a philosopher's personality and the theory he develops. For more on this see J. Pieter, Psychologia filozofowania, Katowice 2005. It should be borne in mind that adoption of a philosophical paradigm is conditional upon subjective factors. In Poland this issue was addressed by Józef Życiński in his writings.

${ }^{61}$ Of course, a philosopher who is self-conscious about his investigations might find such statements to be disparaging about his creative work. However, the author of these words does not mean disparagement of philosophers, but rather an attempt at a realistic approach to that which the socalled "good philosophical work" is about. In the author's estimation it is nothing else but an attempt at dealing with specific, so-called problem situations which emerge in both the field of philosophy itself and at the interface of various sciences, e.g. philosophy and empirical sciences or philosophy and social sciences. Confrontation with a problematic situation releases tentative interpretative hypotheses aimed at explicating that problem situation without pointing to some magical final solution. These hypotheses are firmly grounded in the existing knowledge which has given rise to the 
the plane of logical justifications there is never any ultimate certainty, unless we decree that ourselves. To some such an attitude may appear to be a manifestation of megalomania and pompous dogmatism defying any refutation. Thought objectivisation is always the case in confrontation with others, who usually hold different views on the same objects, events and other people. This results in the conclusion that there is no single viewpoint, not only in the world of everyday experience, but also not in science, which is democratic enough to allow of a multitude of various perspectives, from which it still demands empirical validation. In this respect philosophy enjoys much greater latitude than science, because it does not have to put its assertions to the test of experimentation.

(8) Ontogenetic data also refute the myth propagated by positivists, whereby cognition is entirely derived from sense data. We do not perceive any sensations or sense data. When we perceive a tree, we do not first see the trunk, bark, leaves or branches, but at once we perceive a certain whole, a certain and definite Gestalt. Cognition of an object is not passive. It is related to interaction with it and recasting it by assimilation. What we perceive is co-shaped by logical and mathematical operations. "Experience is only possible through logico-mathematical forms comprising classification, order assignment, correspondence, function, etc. Reading out perceptive data in itself presupposes involvement of such forms or their more or less varied outlines." ${ }^{32}$ Many of the concepts we use, both every day and in science, are not directly derived from

problem situation. In this sense, if at the starting point someone decrees that they have definitively resolved a problem situation, with a formula uttered in a somewhat bombastic way, then he appears to evince some "childish" mannerism whereby everything must necessarily be the way he thinks and decides within his concept. The world is the way his concept states, admitting of no other option, and all other concepts are erroneous only because they are predicated on different premises than his own concept. In my opinion, such unfortunate propositions are a consequence of specific subjective determinants characterised by the predominance of some visionary element rather than logical justification of theses. And herein lie the possibilities for the research by such a metascience as psychology of philosophising.

${ }^{62}$ J. Piaget, Psychologia i epistemologia, op. cit., p. 82. 
experience. ${ }^{63}$ Such concepts as time, space, causation could never be derived from experience, if not for the involvement of increasingly complex formal operations. For instance, in order to obtain the concept of space or causation, it is it necessary to connect data furnished by experience with the subject's formal actions and operations which constitute a system of specific logical and mathematical relationships without which the subject could never assimilate any objects. ${ }^{64}$ Perception always presupposes involvement of conceptual factors, more or less elaborate inferences, with the aid of which the data provided by perception become transformed into increasingly complex operational structures. All this goes to support the arguments against all kinds of propositions of presuppositionless and neutral starting points (Thomism), the adherents of which look for indisputable and atheoretical data. It is all the more difficult to defend them in the case of such theoretically advanced theories that can be found in philosophy/metaphysics. One might say that childish "why" questions are theorised only to a slight degree, which is related to conceptual deficiency and inadequate language and vocabulary. As regards philosophy every question that is posed is predicated on a number of very strong theoretical assumptions without which formulating it would be pragmatically impossible. Complete neutrality and presuppositionlessness could only occur in the case of the so-called unadorned sensation, and would apply to a very early period in the life of a small child who has not acquired skills at using language or categorising perceptive data yet. That is why at no stage of ontogenesis is cognition about passive reading of perceptive data. After all, every experience entails specific formal actions and operations. Perceptions themselves organise themselves in such a manner that an outline of a concept arises within

${ }^{63}$ The real world is not an open book in which one is free to read any theory. In order to "read out" anything of this world, one needs to accept a number of different theoretical assumptions, e.g. basic ones like those concerned with language semantics. The metaphor of "reading the world" brings mistaken associations whereby it might be possible to formulate theories without accepting any premises. Opening one's eyes alone is not enough to get to know the real world, of which, for instance, Piaget's theory of ontogenesis makes us acutely aware.

${ }^{64}$ See J. Piaget, Psychologia i epistemologia, op. cit., pp. 95-96. 
them. ${ }^{65}$ Piaget notes that the organisation of concepts involves sense and motor schemas, which from the viewpoint of ontogenesis play quite an important role, because they lead to the transformation of perceptive data into higher operational units. The more cognitive development progresses and becomes increasingly complex, the more human cognition becomes detached from things and focuses on the logical justification of judgements. ${ }^{66}$ This does not, however, mean that man loses interest in the real world. For he still lives in it and subjects all his cognitive actions to the acquisition of information, which enables his effective adjustment to it, but no longer on an ego-centric or animistic basis, but a realistic one. ${ }^{67}$ Capacity for thought detached from things is an indication of normal mental and cognitive development. It contributes to the development of ability to make more and more skilful use of formal operations which are not concerned with things, but relationships between judgements and concepts. All this is not a sign of any apriorism, idealism or degeneration of cognition, ${ }^{68}$ resulting from abandoning some standard philosophical doctrine, but of normal and proper development determined by the laws of biological evolution. ${ }^{69}$ Because of this, the dilemma over whether "to acquire cognition or think" is from the viewpoint of ontogenesis illegitimate and empirically groundless. Thinking and acquiring cognition constitute a certain functional unity (whole), which even for the sake of more in-depth epistemological analysis should not be splintered. ${ }^{70}$ In all

65 See J. Piaget, Psychologia i epistemologia, op. cit., p. 90.

${ }^{66}$ In the opinion of existential Thomists, it is our capacity for abstract thinking that makes us detach ourselves from that which is real and focus our mind on mental and essential aspects.

${ }^{67}$ The realistic attitude is one which prescinds from things instead of clinging tightly to them. The realistic attitude is one which prescinds from things instead of clinging tightly to them.

${ }^{68}$ Such propositions are common in works by Thomist authors, e.g. Gilson and Krąpiec, and his students, who essentially restrict themselves to repeating his opinions.

${ }^{69}$ Here I omit a broader context of the discussion on the use of evolutionary theory data in philosophical epistemology. At greater length these problems have been discussed as part of the evolutionary theory of cognition, which needs to be clearly distinguished from the concept of ontogenesis as approached by Piaget.

70 Thomists agree that human cognition constitutes a certain functional whole. However, they abide by these alternatives, especially in their criticism of various idealist systems. They connect realism with cognition, and idealism with thinking detached from a concretum. Abstract thinking is 
of man's cognitive functioning it would be difficult to find such moments in which he either only thinks or only acquires cognition. Perhaps only some philosophers (Thomists) know where the one ends and the other begins, and who can function in exactly this way. And that is why in this respect they can be real masters at drawing distinctions, but the question remains whether those distinctions are fortunate...

\section{Final remarks}

The analyses performed show that the conclusions drawn from the ontogenesis of cognition may challenge a number of findings which are concerned with the metaphysics of cognition, and which relate to the status of the "why" question, the nature and goals of cognition, the relationship between language and the world, as well as the realism of cognition and the manner of its justification. However, these conclusions do not definitively prejudge the value of any metaphysical endeavour. And that is why they do not need to be viewed as normative. They are sure to be rejected by many, which in philosophy is an absolutely normal situation and should not result in emotions running too high. A philosopher has some considerable latitude - in his analyses he can take into account data of empirical sciences, but he does not have to that. He may as well claim that they are of no conclusive significance for philosophy. ${ }^{71}$ But when we adopt a multi-faceted approach to the study of philosophical problems, we need to take account of the findings of empirical sciences. ${ }^{72}$

suspicious exactly because it is detached from a real concretum. This thesis is conceptual (speculative) and finds no justification in any data of experience, because the latter actually justifies the opposite: thinking and cognition constitute a realistic whole. Realism is not just a realism of cognition, but also a realism of thinking capable of becoming detached from the concrete and individual.

${ }^{71}$ Existential Thomists believe that the so-called scientific facts cannot disprove philosophical theses, because they are on a completely different epistemological plane than philosophical cognition. Hence, Thomist authors are likely to reject the presented arguments as an attempt at an a priori imposition on philosophy of data derived from ontogenesis, that is from a different cognitive plane.

72 See J. Życiński, Filozofować w kontekście nauki, in: Rozmowy o filozofii, ed. A. Zieliński, M. Bagiński, J. Wojtysiak, Lublin 1996, pp. 213-248; J. Życiński, Wpływ nauk szczegółowych na 
As regards epistemology, that may be about developmental psychology data. Not only are they helpful in correcting certain assertions of the metaphysics of cognition, but they also safeguard against propounding exotic theses which can be by no means corroborated by man's mental or cognitive development. Ontogenesis does not show that the "why" question should be given up in the philosophical discourse. It just implies that this question is perhaps not the most important one for the methodological identity of philosophy, and particularly for metaphysics. Perhaps it should be included within the context comprising all other questions posed by the cognisant subject, because only then can we obtain a more realistic picture of the cognitive situation of man, who asks different questions, looking for more or less lasting answers.

Therefore, it is worth giving some more serious thought to the metatheoretical implications of the ontogenesis of cognition for the construction of a philosophical theory. They might prove helpful in the increasingly realistic depiction of the structure and function of human cognition in its multi-faceted relationships with the real reality.

\begin{abstract}
The question "why" is generally thought to be one of the most important of philosophical questions. Indeed, many philosophers hold that it is responsible for defining the essential contours and identity of philosophical discourse itself. Moreover, all attempts to reject it are perceived as a manifestation of minimalist tendencies in philosophical research. This article presents Piaget's views concerning the ontogenesis of the "why" question. After having reconstructed the latter, it seeks to spell out their potential philosophical implications. The author argues that ontogenetic considerations can certainly play a heuristic role in the formulation of philosophical theses and hypotheses, and that they can lead to a correcting of the conceptions we tend to have of certain philosophical questions - namely, ones that do not refer to any empirical data.
\end{abstract}

rozwój filozofii, in: J. Życiński, Teizm i filozofia analityczna, vol. 2, Kraków 1988, passim. 


\section{Keywords}

Genetic epistemology, epistemology, philosophy of science, Thomism, developmental psychology

\section{Bibliography}

Ajdukiewicz K., Analiza semantyczna zdania pytajnego, „Ruch Filozoficzny” 10 (1926), pp. 194-195.

Ajdukiewicz K., O intencji pytania „Co to jest?”, „Ruch Filozoficzny” 7 (1923), pp. 152-153. Brożek A., O pojęciach rozstrzygalności i nierozstrzygalności w świetle teorii pytań, [in:] Філософсвкі проблеми науки/Filozoficzne problemy nauki, ed. A. Brożek, ЛьвівWarszawa 2008, pp. 355-363.

Brożek A., O pytaniach filozoficznych i ich rozstrzygalności, „Studia Philosophiae Christianae" 45 (2009) no. 1, pp. 7-25.

Brożek A., Pytania i odpowiedzi. Tło filozoficzne, teoria, zastosowania praktyczne, Warszawa 2007.

Duchliński P., W stronę aporetycznej filozofii klasycznej, Kraków 2014.

Fisher R., Stawianie pytań, [in:] R. Fisher, Uczymy, jak uczyć, Warszawa 1999.

Hajduk Z., Filozofia przyrody - filozofia przyrodoznawstwa. Metakosmologia, Lublin 2004. Kamiński S., Jak filozofować. Studia z metodologii filozofii klasycznej, Lublin 1989.

Kielar-Turska M., Przedmowa, [in:] J. Piaget, Mowa i myślenie dziecka, trans. J. Kołudzka, Warszawa 2005, pp. 3-10.

Kielar-Turska M., Średnie dzieciństwo. Wiek przedszkolny, [in:] Psychologia rozwoju człowieka. Podręcznik akademicki, ed. J. Trempała, Warszawa 2011, pp. 83-129.

Koj L., Analiza pytań I. Problem terminów pierwotnych logiki pytań, „Studia Semiotyczne” 2 (1971), pp. 99-113.

Koj L., Analiza pytań II. Rozważania nad struktura pytań, „Studia Semiotyczne” 3 (1973), pp. 22-39.

Krąpiec A. M., DIÁ TÍ, http://www.ptta.pl/pef/pdf/d/diati.pdf (31.01.2018).

Krąpiec A. M., Filozofia co wyjaśnia, Lublin 1999.

Krąpiec A. M., Metafizyka. Zarys teorii bytu, Lublin 1994.

Krąpiec A. M., O rozumienie filozofii, Lublin 1995.

Krąpiec A. M., Poznawać czy myśleć: problemy epistemologii tomistycznej, Lublin 2000. 
Krüger H. H., Wprowadzenie w teorie i metody badawcze nauk o wychowaniu, trans. D. Sztobryn, compiled by B. Śliwerski, Gdańsk 2005.

Kubiński T., Analiza logiczna pojęć a założenia pytania, [in:] Rozprawy filozoficzne, ed. L. Gumański, Toruń 1969, pp. 189-200.

Kubiński T., O pojęciu pytania i rachunku operatorów pytajnych, „Ruch Filozoficzny” 25 (1966) no. 1-2, pp. 70-74.

Pelc J., O poznawczej roli pytań, [in:] Prace z pragmatyki, semantyki i metodologii semiotyki, ed. J. Pelc, Wrocław 1991, pp. 191-200.

Piaget J., Jak dziecko wyobraża sobie świat, trans. M. Gawlik, Warszawa 2006.

Piaget J., Mowa i myślenie dziecka, trans. J. Kołudzka, Warszawa 2005.

Piaget J., Psychologia i epistemologia, trans. Z. Zakrzewska, Warszawa 1977.

Pieter J., Psychologia filozofowania, Katowice 2005.

Psycholingwistyka, ed. G. Gleason, J. \& B. N. Ratner, trans. J. Bobryk, Gdańsk 2005.

Radwiłowicz R., O pytaniach uczniowskich ogólnie, [in:] Pytania uczniów a treść nauczania, ed. R. Radwiłowicz, K. Pauzewicz, C. Kosiński Warszawa 1969, pp. 7-21.

Stępień B. A., Wprowadzenie do metafizyki, Kraków 1964.

Stróżewski W., Istnienie i sens, Kraków 1994.

Stróżewski W., O zasadnicze pytanie metafizyki, „Znak” 127 (1965), pp. 3-23.

Szuman S., Rozwój pytań dziecka. Badania nad rozwojem umysłowości dziecka na tle jego pytań, [in:] Studia nad rozwojem psychicznym dziecka, selected and prepared by M. Przetacznikowa, G. Makiełło-Jarża, Warszawa 1985, pp. 274-321.

Szuman S., Rozwój pytań dziecka. Badania nad rozwojem umysłowości dziecka na tle jego pytań, Warszawa 1939.

Turek J., Filozoficzne interpretacje faktów naukowych, Lublin 2009.

Turek J., Implikacje ontologiczne typu redukcyjnego jako metoda uprawiania filozofii przez Księdza Profesora Kazimierza Kłósaka, [in:] Filozofia a nauka w myśli - Księdza Kazimierza Kłósaka, ed. Z. Liana, A. Michalik, Kraków-Tarnów 2004, pp. 63-88.

Wiśniewski A., The Posing of Questions: Logical Foundations of Erotetic Inferences, Dordrecht-Boston-London, 1995.

Wojtysiak J., „Dlaczego istnieje raczej coś niż nic?” Analiza problemu w kontekście dyskusji we współczesnej filozofii analitycznej, Lublin 2008.

Wojtysiak J., O zasadzie racji dostatecznej, „Roczniki Filozoficzne” 54 (2006) no. 1, pp. 179-21. 
Woleński J., Logika, kontekst odkrycia, kontekst uzasadniania,[in:] Odkrycie naukowe i inne zagadnienia współczesnej filozofii i nauki. Pamięci Elżbiety Pietruskiej-Madej i Jana Żytkowa, ed. W. Krajewski, W. Strawiński, Warszawa 2003, pp. 75-87.

Woleński J., O tak zwanych filozoficznych założeniach nauki, [in:] Z zagadnień filozofii nauk przyrodniczych, ed. S. Butryma, Warszawa 1991, pp. 7-16.

Woleński J., W stronę logiki, Kraków 1996.

Zamiara K., Epistemologia genetyczna Piageta a społeczny rozwój nauki, Warszawa-Poznań 1979.

Zamiara K., Epistemologiczne założenia psychologicznej wizji człowieka, [in:] Materiały XXVI Zjazdu PTP, Szczecin 1987, ed. E. Aranowska, Warszawa 1991.

Zamiara K., Kilka uwag o Piagetowskiej koncepcji świadomości i jej znaczeniu dla badań nad kultura, „Nowa Krytyka” 1991 no. 1, pp. 33-44.

Zamiara J., Obecność myślenia psychologicznego w epistemologii, [in:] Rozprawy i szkice $z$ filozofii i metodologii nauk, ed. J. Such et al., Warszawa-Poznań 1992.

Życiński J., Filozofować w kontekście nauki, [in:] Rozmowy o filozofii, ed. A. Zieliński, M. Bagiński, J. Wojtysiak Lublin 1996, pp. 213-248.

Życiński J., Wpływ nauk szczegółowych na rozwój filozofii, [in:] J. Życiński, Teizm i filozofia analityczna, vol. 2, Kraków 1988.

Życiński J., Zagadnienie możliwości falsyfikacji twierdzeń w filozofii przyrody, „Analecta Cracoviensia" 14 (1982), pp. 94-98. 